\title{
F5 Gene
}

National Cancer Institute

\section{Source}

National Cancer Institute. F5 Gene. NCI Thesaurus. Code C91332.

This gene plays a role in coagulation. 